\title{
THE ANALYSIS OF EFL LEARNING STRATEGY OF THE VISUALLY IMPAIRED JUNIOR HIGH SCHOOL STUDENTS
}

\author{
N.M.Y. Setyawati ${ }^{1}$, L.D.S. Adnyani ${ }^{2}$,K.S. Piscayanti ${ }^{2}$ \\ ${ }^{1}$ Batu Mejan Kulina Sukses Bersama \\ ${ }^{2}$ Universitas Pendidikan Ganesha \\ e-mail : nimadeyuni.setyawati@gmail.com, luh_diah@yahoo.com, sonia.piscayanti@undiksha.ac.id
}

\begin{abstract}
This study aimed to describe about the learning strategies that the visually impaired students (VIS) used in learning EFL as what explained by Oxford (2005) that during a learning process, strategies used by the learners depend on their motivation, background, age, learning style, achievement, and gender. It was found that there are 6 strategies used, they are (1) cognitive such as practicing, repeating, getting idea, analyzing and reasoning, summarizing and translating; (2) metacognitive, they are paying attention to the lesson and showing evidence of understanding; (3) social strategy, they are empathizing with others, asking questions, asking for a review, asking for additional input, and asking for confirmation; (4) affective, by decreasing their anxiety; (5) memory, by making associations, contextualizing words, recalling, resorting to visual residue, wrapping up, and retaking previous ideas; (6) compensation, by overcoming limitations in speaking and writing, attempting to give an answer, and using language mixing. Thus, visually impaired students must be treated special to cover their needs with appropriate teaching strategies and facilities.
\end{abstract}

Keywords: EFL, learning style, visually impaired, strategies

\section{INTRODUCTION}

Education is for everyone, which means that all can get education. No matter how the condition of the learners are, all people have right to be educated. It is including the students with special needs, like the visually impaired students. They need to be treated special because they are less able since they got visual impairment that hamper them to follow the education as what normal people got. Quatraro (2009) explained that the importance of English as a foreign language for visually impaired students is that English is the only one way that they can use to reach a relationship with wider society, especially to communicate with foreigners. In learning EFL, they are more curious than the normal students. They cannot do skim reading either, it means that they must read by using braille. Besides, Zulfa, Noor, and Ribawanto (2013) explained that the visually impaired students are given different level of education, especially in English subject. In the elementary school, they are prepared to be able to follow the programs decided in the Junior
High School grade. Next, in the junior high school, they are prepared to be able to build a good relationship in the society including the way to communicate well in social environment. However, in the senior high school, they are given specific education to prepare themselves to get jobs for their future. It shows that the education they get in junior high school needs to be emphasized because in that phase, they are prepared to be able to build good relationships in their society. The students with visual impairment communicate by using normal language in communicating in their daily life. In other words, they do not use any special language to communicate, and it is different from students with deaf and students with mute (Fatima, et.al, 2014). It makes the visually impaired students are able to speak English and learn English. Then, they also have different psychological condition with normal students which make them hard to learn to communicate, especially to learn to communicate using EFL (Ramos, 2017). Then, the result of this study is expected to give more 
ideas to the special education teacher after getting knowledge about the learning strategies they used in learning EFL.

Besides, the learning strategy depends on one's motivation, habit, background, learning style, and other characteristics they have. Besides, the students' goal also affects the learning strategy used by the learners. The way they learn influences their language achievement. When they are excited and motivated to learn because of those factors, they must be able to encourage themselves to learn and empower the language they learn (Zare, 2012). He also proposed that when the students use good strategies or vary strategies in their language learning processes, they are easier to empower the language they want to. It is because they use the appropriate ways or techniques in understanding the language; it makes them comfortable to learn it. Moreover, according to Zulfa, et.al (2013), the students with visual impairment are categorized into students that need special education which means that they are treated based on their own needs. Visually impaired students are also given knowledge based on their grade. Zulfa et.al (2013) clearly explained that the visually impaired students who are in the elementary school are prepared to be able to follow the programs in the Junior High School grade. In the senior high school, they are given specific education to prepare themselves to get jobs for their future. Based on that explanation, the students with visual impairment also get knowledge about how to socialize in society when they are in junior high school. Socialization itself is related with communication, including English communication that is used to build relationship with people in society. That is why English communication is the only bridge that students with visual impairment can use to communicate with people from other cultures all around the world and their ability to communicate depends on their English education that they get in when they are in junior high school (Quatraro, 2009). Therefore, this topic is really interesting to be analyzed in order to get deeper understanding about the strategies they use to learn EFL.

\section{LITERATURE REVIEW}

According to Oxford (2005), everyone learn about something by using his strategy in which that strategy is related to the factors affect the way people learn. He also stated that during a learning process, strategies used by the learners depend on their motivation, background, age, learning style, achievement, and gender. Griffiths (2013) explained that there are four factors that affect the language learning strategy used by students in learning a target language. They are the students' goals in learning that language, the environment where the language learners belong to, the selection of the language, and the personal situation of the learners itself. He also argued that those have a significant role in determining the learners' or the students' learning strategy. Moreover, Zare (2012) also explained that the learning strategy of students really affect the process of language learning in the classroom. He also stressed that when the students learn by using a good strategy, they will get a good achievement. It is because they use a good technique, and a good way to get the knowledge they learn, so they provide themselves effective ways that help them understand the material well.

Oxford (2003) proposed that the language learning strategy is defined as a certain behavior or thoughts that they use as a specific way to understand the language. Then, Zare (2012) argued that language learning is special ways used by the students to increase their comprehension about language. Then, Oxford (2005) explained that the language learning strategy used by students in learning a language is including the goals and the purposes of their learning process. It can be concluded that the students are categorized to have a language learning strategy when they have an exact plan to be conducted when their language learning to process. In addition, they also plan about the goal they must achieve by conducting that plan. In addition, Zare (2012) highlighted that language learners can be successful in achieving their learning goals in learning language if they use wider range of strategies. Those strategies will be related each other to get the goals. 
Based on Oxford (2003), there are two kinds of language learning strategy; they are direct and indirect language learning strategy. The direct language learning strategy is divided into three points. The first one is memory. This is including relating the memory with the thing that they see, imagining the thing or the sound if it is a sound, making a review and takes an action. The second one is cognitive strategies. In this part, the students are manipulating the language they hear and trying to get the meaning of it. This can be done by practicing, repeating, analyzing the words, and structuring. The third one is compensation strategies. Oxford (2003) clearly stated that this strategy include an activity which enables the students to guess the words intelligently and overcoming limitation that can be done by practicing to speak and write.

The next one is about indirect strategies that include three points. The first one is metacognitive strategies that involve focusing the thing that would be learnt, making plans, and evaluating the plans conducted. The second one is affective strategies. Oxford (1990) clearly explained that this is about the strategies that students use to be brave, encourage themselves, and also to take down their emotional. The third one is social strategies which is including asking questions to others about what that they do not know and also cooperate with others to know something that they do not understand (Oxford, 1990). Ramos (2017) explained that during their EFL learning process, the visually impaired students are practicing, doing repetition, getting idea quickly, analyzing and reasoning, creating structure for input and output, summarizing, and translating English by their first language (Ramos, 2017). Those activities are categorized as cognitive strategies. Besides, she also clearly stated that to comprehend the English, the techniques used by the visual impaired students are evaluating and monitoring the learning, paying attention, delaying speech production to focus on listening, showing evidence of understanding or analysis. Those activities are determined as metacognitive strategies. The next strategy used by students with visual impairment is called social strategies which involve empathizing with others, asking questions, asking for confirmation, following the conversation, asking for a review, getting recognition, asking for additional input (Ramos, 2017). The fourth is affective strategy which is done by keep laughing to make a friendly dialogue and also be brave to decrease anxiety. The other strategies are memory. Ramos (2017) clearly stated that the activities done are making associations, contextualizing words, recalling, resorting to visual residue, wrapping up, retaking previous ideas. The last strategies conducted by visually impaired students are compensation strategies they are including guessing intelligently, overcoming limitations in speaking and writing, approximating and coining words, description, attempting to give an answer, Language mixing, code-switching (Ramos, 2017).

In language learning, there are several factors that affect people especially visually impaired students to acquire the language (Oroujlou \& Vahedi, 2011). They are sex, age, characteristics, personality, and motivation. However, among those factors, the only factor that affects the language acquirement the most is motivation. Besides, he also argues that when students are motivated, they are encouraged to reach their goals that are to empower the language. Related to motivation, Sansone and Harackiwiz (2000) argue that there are two kinds of motivation, they are extrinsic and intrinsic. Extrinsic motivation is a kind of motivation in order to get reward, so it means that when the students are motivated to learn EFL in order to get reward from their society, they are motivated extrinsically. However, intrinsic motivation is that people are interested to learn EFL or get pleasant when learning EFL. On the other words, the students are truly interested to empower EFL.

\section{METHODOLOGY}

The main focus of this study is what about their learning strategies during their EFL learning process.

\section{Research Design}

This study was designed qualitatively. The major approach used in this study was descriptive qualitative since this research is 
mainly focused on the things experienced by the visually impaired students. This study was conducted in SLB Negeri 1 Denpasar that is located in downtown at J. Serma Mayor Gede, No.11 Denpasar. SLB Negeri 1 Denpasar is one of special education schools in Bali that provides special education for students with special needs, especially students with visual impairments. The participants of this study were the junior high school students with visual impairment in SLB 1 Negeri Denpasar. The numbers of the students were 12 students. They were divided into 3 grades, 5 students were from the 7th grade, 5 students from 8th grade, and 2 students from 9th grade. Those participants were selected by using saturation sampling technique.

\section{Data Collection and Analysis}

The data were gathered in 4 ways, they are observation, interview, note taking, and documentation. The first one is classroom observation, in this study; the type of observation used was the natural observation. In this case, the subject was observed. What was observed is about the strategy used by the students during their process in learning EFL. The teaching and learning process conducted in the classroom was observed naturally without any setting. Next is interview guide. All students chosen as the sample of this study were asked about some questions related to their strategies in learning EFL. The next one is note taking, note was taken during this study to get the emphasis of the review about the data collected. The last is documentation. From the observation and the interview are beginning, the researcher keep recoding it, so the data can be more analyzed if there is already the proof of the collecting data. Next, the data gained were analyzed by using the qualitative data analysis from Miles, Huberman, and Saldana (2014). It was started from collecting the data. The next is data display in which all of the data were organized based on the answer of the questions. The data gathered from the interview section were transcript. The data gained from the observation, note taking, and the documentation section was categorized based on the topic. Then, it was continued by data analysis which was done by categorizing the data based on its dimension to get deeper understanding. After the answer gained, it was followed by drawing conclusion.

\section{FINDINGS AND DISCUSSION}

After several instruments, observation, interview, note taking, and documentation were conducted, this study concludes the result of the main problem that is about the strategies used by the visually impaired students in learning EFL. It was found that there were six EFL learning strategies used by the visually junior high school students. The first is cognitive strategy. Oxford (2011) explained that cognitive strategy is all activities that help the learners remember the language they learn. Then, the use of cognitive strategy in this study was proven by the use of both practicing listening and practicing speaking. They practiced listening by listening to English songs which enabled them to listen to the English words pronunciation in order to make themselves used to it. They also practiced speaking by singing English songs, pronouncing new English words, and talking with friends using English mixed Bahasa. Next is repetition. In order to memorize how words pronounced, they repeated the words pronunciation and the words meaning over and over again. Based on the findings, ten of the twelve students repeated the words pronunciation to be able to memorize it. Eleven students got idea in their EFL learning process. When they did not know the meaning of certain words or sentence, they asked the interpretation in Bahasa so they got idea related to EFL. They also analyzed and reasoned by associating the things that they learned with the things that they experienced. For example, the English words that they learned in the classroom with their teacher and friends, when they heard the words outside the classroom; they rememorized the meaning of the words that they had learned. Most of them often summarized the meaning of certain words that they learned based on the information that they got from people around them. After that, they visualized it in their minds, and then decided the meanings. Next is translating. In order to help themselves understand the meaning of English words, they always asked the meaning of certain English words in Bahasa 
or certain Indonesian words in English. This result is also correlated with what was found by Ramos (2017) that in learning EFL, visually impaired students are using cognitive strategy, however he found that the activities are practicing, repetition, receiving and sending messages: getting the idea quickly, analyzing and reasoning, creating structure for input and output, summarizing, translating, using $L 1$. It means that the result of this study is quite different from the previous study conducted by Ramos (2017) in which this study only found that the visually impaired students used cognitive strategy, by conducting several activities like practicing, repetition, summarizing, and translating.

The second strategy used is metacognitive strategy. Metacognitive strategy is a language learning strategy that is used in order to help the learners focused on the lesson during their language learning process (Oxford, 2003). The students used it by paying attention to the English words pronunciation and to the English words description. This result is supported by Hadi (2007). He clearly explained that the listening ability of the visually impaired students must be improved in order to help them to keep focus on the lesson. Next is showing evidence of understanding. This was encouraged by the data gained from the observation; it is as the following bellow.

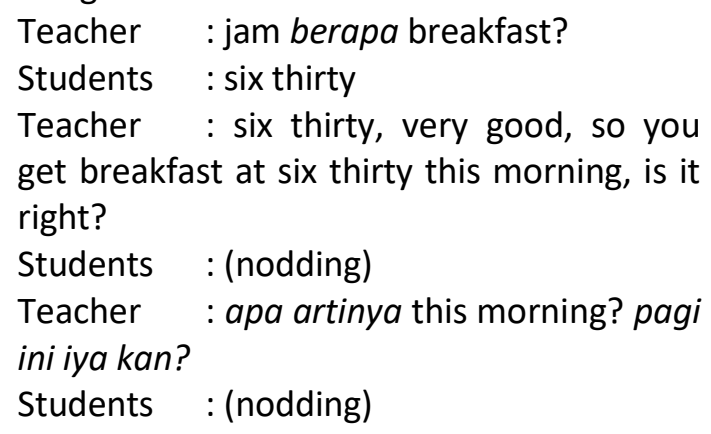

For the 8th grade students, three students was found that they nodded and said "ooh", "yes", "yes, I understand", and two students were found that they nodded only. The data were also gained from the observation which indicates that the students smiled and nodded when they understood the explanation given. It could be seen from the part of the conversation in the classroom during the classroom observation.
Teacher : okay. If somebody introduces hmm... each other, they need to shake their hands. Okay?

Students : (keep silent)

Teacher : they need to shake hands (while shaking hands with them to tell what he means) like that, okay?

Students : (they are nodding)

Teacher : and then, say the name, okay?

Students : (they are nodding)

Teacher : nanti cukup bilang nama aja, okay?

Students : (they are nodding)

For the 9th grade students, one said that he usually nodded and smiled when he understood about what was explained. However, one student said that she usually said "ooh" and nodded to show that she understood the lesson or everything that was explained by the teacher.

Teacher : yaa, apa yang sedang kamu lakukan, sedang berlangsung, yang sedng berlangsung right? Kira-kira kalimat yang lain apa? "What are you doing?", "I am sitting", "I am laughing", yang lainnya kirakira apa?

Students : I am speaking
Teacher : hmm?
Students : I am speaking.
Teacher : Very good. Itu namanya
menyatakan sesuatu yang sedang
berlangsung. Tenses nya itu continuous
tense, simple continuous tense.
Students : (they are nodding to show that
they understand)

All of them explained that they always did it every time they got English lesson, so it is about once a week because they only got English once a week. It means that the visually impaired students always showed evidence to indicate that they understood about what their friends or teacher said to them.

The third strategy is social strategy. The findings showed that from twelve visually impaired junior high school students, nine of them empathized with others. It could be seen from what they admitted that they always thought that they must be able to use EFL if their friends can. Even though all of them 
thought that they were less able, they keep thinking that way since they wanted to have the same level as sighted students have. This result is related with what was explained by Hadi (2007) who states that their visual impairment also give positive impact to their language learning process. He clearly proposed that visually impaired students always want to have the same level with normal people and do not want to depend on normal people. Besides, most of the visually impaired students usually asked questions related to the meaning of English words in Bahasa or the meaning of Indonesian words in English. All of the visually impaired students also asked how certain English words pronounced. When they found complicated words, they always asked their teacher directly to know how the pronunciation. This shows that the visually impaired students tried to get information about how words defined in Bahasa or in English and how English words should be pronounced by asking it to their friends of their teacher.

The examples of the words that had ever asked by the 7th grade students to their teacher / friends are the meaning of: "just", "pencil", "book", "eraser", "bag", "ruler", "Melanie read a book in a living room".

The examples of the words that had ever asked by the 8th grade students to their teacher / friends are the meaning of: "television", "clock", "red", "white", "table", they also asked about the meaning of the whole story that was told by the teacher.

The meaning of words asked by the 9th grade students were: "car", "grab", "chair", "table", "barking", and "bark".

Moreover, the teacher added that the students often asked questions related to the words meaning, and they directly asked when they were being explained something. He stated that the students usually asked, "apa artinya itu pak? hehe" which means "what does it mean sir?". "It" here refers to the teacher's explanation that was using English. Then, the students exclaimed that question to get the translation of what the teacher explained because they did not understand what he said in English.
Not only asking questions, they also asked for confirmation in order to make sure how certain words pronounced and the meaning of certain words. This indicates that the students know the meaning of the English words in Bahasa, or how the English vocabularies must be pronounced, however, they still doubted of it that was why they confirmed it to their friends or teacher to make sure its meaning. In addition, some visually impaired students usually asked for a review, whether it is about the way how they pronounced English words or a review about the sentences they made. Those students usually asked for the comment or suggestion about their speaking or the way their pronunciation when speaking English. The findings showed that there were only five students who usually asked for additional input from others. They did it by asking suggestion to their friends of their teacher about how words should be pronounced. For example, they had ever asked for suggestion about how the words "down" and "street" should be pronounced since it was caused by the difference of words pronunciation with the written text. The use of those activities by most of the visually impaired students shows that they used social strategy during their EFL learning strategy. This result is compatible with Ramos (2017) as she agrees that the visually impaired students use social strategy in learning EFL. However, she only found that the most visually impaired students commonly used asking for confirmation, getting recognition, asking questions, and asking for additional input as parts of social strategy.

The next strategy used is affective strategy. As what explained by Oxford (2003), affective strategy is related to the learners emotional situation. However, the finding shows that the visually impaired students in SLB N 1 Denpasar used this strategy, but it was proved only by decreasing their anxiety in speaking English. Even they were nervous when asked speaking in front of the class and unconfident with their answer, but they kept telling their ideas in order to decrease the anxiety they have. This shows that, they tried to attract the anxiety they have. This result is also supported by what Ramos (2017) found in her study that the visually impaired students use affective strategy in their 
EFL learning process. She found that they only lower their anxiety and use laugh to keep a friendly dialogue which are parts of the affective strategy. As what explained by Oxford (1990), affective strategy is related to the learners emotional situation. Even though they were nervous when asked speaking in front of the class and unconfident with their answer, but they kept telling their ideas in order to decrease the anxiety they have. This result is also in line with Ramos (2017) as she found that socioaffective is a common strategy used by the visually impaired students.

The fifth one is memory strategy. This strategy is associated with the things that the language learners see, then imagining the sound that they hear, reviewing it and takes an action of it (Oxford, 2003). It was found that 9 of the 12 visually impaired students were usually making association of the words that they heard with the words that they had ever learned with their teacher and their friends. By making association of the words they hear with the English vocabularies, they knew new meaning of English vocabularies. The interview result shows that nine of the 12 students admitted that they often made associations about what they had ever listened to with their experiences. Four of them were from 7th grade and they said that they always associated everything that they heard to their experiences, especially the meaning of certain words when they listen to English explanation. The examples of the associations they made are:

The word "cow" to the word "dancow"

The word "ghost house" to the word "horror story"

The word "with you" to song they had ever heard

The word "classroom" to the teacher's explanation

Three of them were from 8th grade, and they said that they often associated what they heard, like English words or sentences, with what they had ever experienced. The examples of the associations that they had ever made are:

The word "horror game" that was associated with the experience when playing a horror game
The word "up to you" that was associated with what the teacher had ever said about the meaning of that statement

The word "movie" that was made the association by memorizing the time when watching film

From their argument, they usually related English words or sentences with their experience, because they did it unconsciously when they learned English. Besides, the last two students that often made associations during their EFL learning were from the 9th grade. As what the other students explained, they also said that they often made associations unconsciously. It was because every time they listened to English conversation or explanation, they directly associated it with the things that they had ever done before. Moreover, the examples of the words associations made are:

The meaning of "bike" with the word "grab bike", because they often ordered "grab bike"

The meaning of word "diligent" that they associated with the sentence that they had ever heard from their teacher that was "my brother is diligent"

In addition, the teacher also had stated that his students only depended on their memory in learning English. It was because every time they were given explanation about something, they would remember it when they were asked again in the next meeting or the next week later. Next activity involved in memory strategy is recalling the English vocabularies. The finding indicated that the visually impaired students were always recalling about the English words that they had learned spontaneously when they listened to English words, whether it was inside or outside the classroom. Next activity was resorting to visual residue. For the visually impaired students, this activity had the most important role in their EFL learning process. Based on the findings, for all of the 12 visually impaired students, resorting to visual residue was the most important thing that they always did when they listened to every English word, whether it was from their teacher or their friends. For them, every time they listened to an explanation, they always resort the words to their visual residue, on the other hand, they 
always imagined in their mind how the things that they heard looked like. Most of the visually impaired students were wrapping up during their EFL learning process. Besides, there were also several examples about how they summarized how things looked like even they had visual impairment that is they usually listened to the information about the words they learned like "house", after listening to the explanation given, they got information about how a house is, and they wrapped up that "a house is a place for living". Not only wrapping up, most of the visually impaired students were also retaking their previous ideas by memorizing the things they had learnt before. The findings also showed that the students were retaking previous ideas by answering their teacher's question related to the words meaning with the vocabularies that they had discussed before. Those activities done by the students mean that the used their memory to memorize and keep the things they had learnt in their mind.

The last strategy used by the visually impaired students is compensation strategy, a language learning strategy in order to make the language learners able to overcome their limitations in speaking and writing (Oxford, 2003). Besides, Ramos (2017) found that the visually impaired students were also using compensation strategy in their EFL learning process, and it was proven by guessing intelligently, overcoming limitations in speaking and writing, approximating and coining words, description, attempting to give an answer, language mixing, and code-switching. Meanwhile, this study found that the visually impaired students in SLB N 1 Denpasar are also using compensation strategy; it was proven by conducting several activities during their EFL learning process. The first one is overcoming limitations in speaking and writing. They overcame their speaking limitations by memorizing the lyric of English songs while singing it even they did it inappropriately; at least they tried to overcome their limitation in pronouncing English words. Besides, they also did speaking practice by repeating English vocabularies they had learned to practice their pronunciation and also talking to their friends by using English mixed with Bahasa, like "why ar you duduk disitu?". However, they overcame their writing limitations by writing the homework they got from the teacher and also rewrite about self-introduction and poetry. They did it to make themselves get used to the English words and so they could memorize how the words written. Then, it also could improve their reading skill by memorizing how English words written and could guess how it should be read. The next activity done was attempting to give answers every time they were asked in English. They tried to introduce themselves by saying simple expressions they already learned with their teacher in the classroom. Besides, when their friends were talking to them by using English outside the class, they also tried to answer by using English. For example, they said:

Other : your eyes like cat

Student : you are crazy. I'm human

It represents that they, whether inside or outside the classroom, they attempted to answer the questions or the expressions uttered to them. Based on the findings above, they tried to overcome their limitation in pronouncing the words since they could not imitate their teacher's pronunciation properly, so they tried to improve their English pronunciation by attempting to give answer every time they were asked questions in English. Beside of attempting to give answers, the most common activity conducted by the visually impaired junior high school in SLB N 1 Denpasar was mixing language. They often mixed both English and Bahasa when talking to their friends and sometimes when talking to their teacher. It was because they forgot or did not know the words they wanted to say in English, so they decided to say the words in Bahasa. For example, one of the mixed sentences they said was "I hope you and keluargamu always be happy". It means that they had effort to communicate in English even they had limited vocabularies.

Thus, students with visual impairment have different psychological condition with students normally. Sometimes they must be treated special because they are less able and must be helped in some occasions. So, there are found challenges during their learning process, moreover in learning English as foreign language. When they find problems, it means 
that the students face problems during their learning process. Then, they must have a kind of strategy that they can use as solution to overcome the problems they face. Besides, Quatraro (2009) explained that during their process in learning EFL, they have fewer vocabularies about English as their foreign language. It is because of their limited chance to get the experience in using certain vocabularies. Besides, it is also because of their disability to see something, this makes the visually impaired students are hard to understand the words contextually, including how the shape and the color of that things (Quatraro, 2009).

\section{CONCLUSION}

In summary, the visually impaired students were using 6 strategies in learning EFL. They are cognitive strategy that was done by practicing, repeating, getting idea, analyzing and reasoning, creating structure, summarizing and translating. The second one is metacognitive which was done by paying attention to the lesson and showing evidence of understanding when learning EFL. The third one is social strategy. It was proved by the application of empathizing with others, asking questions, asking for a review, asking for additional input, and asking for confirmation to others in their language learning process. The forth is affective strategy. It could be said so because they kept telling their ideas in order to decrease the anxiety they have when they are doubt. The fifth one is memory strategy. It is indicated by making associations, contextualizing words, recalling, resorting to visual residue, wrapping up, and retaking previous ideas that were done by the visually impaired students during their EFL learning process. The last strategy used is compensation strategy. Guessing intelligently, overcoming limitations in speaking and writing, attempting to give an answer, and using language mixing during their EFL learning process showed that the visually impaired junior high school students in SLB N 1 Denpasar used this strategy in their EFL learning process.

\section{SUGGESTION}

The visually impaired students should to be treated the same as how teachers treated normal students. This is in order to make the students feel comfortable during the lesson and they will never think that they are different because they are less able. So, when they feel more comfortable, they will think that they have the same right as what normal people have in this world. Besides, they should also be provided the same facilities as what other schools have to teach their students, including classroom facilities until the students' needs, like book, and stationaries. In SLB N 1 Denpasar, they did not even get English braille hand book from the school that they could use to learn English. It limited the students' chance to improve their English because they had no English book to be read. So, they could not read and write, especially braille English text. Besides, the teacher should also be more responsible in facilitating the students enough time to learn in the classroom, since all of the students complained that they rarely got English lesson while they were really excited every time their English teacher came to the class.

\section{REFERENCES}

Fatima, G. (2014, May). Difficulties Faced by Students with Visual Impairment Registered in Open and Distance Learning Programs of AIOU, Islamabad, Pakistan (Vol. 5(3)). Pakistan: Academic Research International.

Ghafri, M. S. AL. (2015). The Challenges that Visually-Impaired Students at Sultaqn Qaboos University Face in Learning English. Malaysia: Kuala Lumpur.

Hadi, P. (2007). Komunikasi Aktif Bagi Tunanetra. Indonesia: Departemen Pendidikan Nasional.

Miles, M. B., Huberman, A. M., \& Saldana, J. (2014). Qualitative Data Analysis (3 ${ }^{\text {rd }} \mathrm{Ed}$.). United States of America: SAGE.

Oroujlou, N., Vahedi, M. (2011). Motivation, attitude, and language learning. The OnLine Journal of Research (On-line serial), 1. Available: Internet: https://www.researchgate.net/publicatio 
n/271638356_Motivation_attitude_and_I anguage_learning. February 16, 2018.

Oxford, R. L. (2003). Language Learning Styles and Strategies. Alabama: GALA.

Oxford, R. L. (2005). Language Learning Strategies Profiles of EFL Elementary School Students in Taiwan. Alabama: Department of Curriculum and Instruction.

Pimentel, C. L. (2018). Problems and Issues Related to Teaching Japanese to Students

Ramos, K. V. (2017). A visually-impaired English learner in the context of virtual environments: analyzing learning strategies. The On-Line Journal of Research (On-line serial), 1. Available: Internet:

http://dx.doi.org/10.14482/zp.22.5832.

February 16, 2018.

Sansone, C., \& Harackiewicz, J. M. (2000). Intrinsic and Extrinsic Motivation. United States of America: Academic Press

Wyse, S. E. (2011). What is the Difference between Qualitative Research and Quantitative Research?. The On-Line Journal of Research (On-line serial), 1. Available: Internet: https://www.snapsurveys.com/blog/wha t-is-the- difference-between-qualitativeresearch-and-quantitative-research/. with Disabilities: Lessons Learned. (Vol. 9). United States: Western Michigan University.

Quatraro, A. (2009). ELLVIS - English Language Learning for Visually Impaired Students. Italian Union: Audiovisual \& Culture Executive Agency

Rajamanickam, M. (2001). Statistical Methods in Psychological and Educational Research. New-Delhi: Ashok Kumar Mittal.

Zare, P. (2012). Language Learning Strategies among EFL/ESL Learners: A Review of Literature. (Vol. 2). Iran: Islamic Azad University.

ZHENG, X. (2014). A Study on Blind Students' Experience of Provision and Support in Schools. The On-Line Journal of Research (On-line serial), 1. Available: Internet: http://www.duo.uio.no/. February 8, 2018.

Zulfa, E.R., Noor, I. \& Ribawanto, H. (2013). Pengembangan Kapasitas Sekolah Luar Biasa Untuk Meningkatkan Pelayanan Pendidikan Bagi Anak Berkebutuhan Khusus. The On-Line Journal of Research (On-line serial), 1. Available: Internet: https://media.neliti.com/media/publicati ons/78054-ID-pengembangan-kapasitassekolah-luar-biasa. February 8, 2018. 